\title{
Conflict: A Mirror in the Social Life Processes
}

\author{
Rudina Hoxha \\ PhD candidate, lecturer, Departament of Sociology, \\ Faculty of Education, 'Aleksander Moisiu' University, Durres, Albania \\ E-mail: rudihoxha@yahoo.com
}

Doi:10.5901/ajis.2013.v2n11p30

\begin{abstract}
This article discusses the role of conflict in society. The main purpose of the study is the confrontation of sociological and political theoretical approaches as two different viewpoints of the same issue, which brings innovation in the crosscut and changes of these relationships in conflict. Democratic rights, economic strength - and how it is distributed - social cohesion, environmental balance and well educated people cannot be separated in today's world. We need more than ever to deal with our common future in a holistic way. The only way democracy will prove itself is through a living relationship between peoples and their governments based on trust, accountability and the determination to deliver practical results. It will also challenge us to look at the evolution of democratic systems and democracy assistance, with particular attention to the impact of changes in the world economy and global communications. It argues for the overriding need to address complexity while always returning to basic principles in practice and process. Therefore, the presentation of different theoretical views through the paper will diversify it and will make the picture much more comprehensible.
\end{abstract}

Keywords: conflict, theoretical view, social groups

\section{Introduction}

Theories of ethnic conflict often assume that the cause of political violence is the same across actors and constant over time. In my idea causes differ, depending upon the identity of the ethnic group we are taking under study and the social context in which it lays its activity.

Explanations for the rise of internal conflicts as the predominant form of war today may be found in analysis that emphasizes the structure of the international system-such as the historical legacy of colonial-era borders that have produced dysfunctional states, or globalization-induced growth of socio-economic inequalities. Some analysts focus on the level of states, suggesting that government policies which promote structured inequality along group lines are a primary cause of violence. Others focus on group and individual-level causes, suggesting that many wars of the last decade or more have been the result of mobilization along divisive ethnic, racial or religious lines amid competition for power. In any event, many of the wars of the last decade or more have been fought with claims of religion, of ethnic identity and security, or over perceived racial differences, and over tough issues such as access to resources, language rights, education, land and territory, and equal status under the law. Horowitz (1985), in his seminal book on ethnic groups in conflict, points out that the most severe conflicts arise in societies where a large ethnic minority faces an ethnic majority.

\section{The Root Causes of Contemporary Conflict}

Conflict analysis identifies these components:

- $\quad$ Type of conflict

- $\quad$ The reasons for the conflict

- $\quad$ The causes and consequences of the conflict

- The components and the different actors involved

- The levels at which the conflict takes place

- The dynamics of conflict

While every conflict will have its specific context and features, there is broad consensus that factors related to grievances over such things as discrimination or inequality are to blame for the rise in contemporary internal conflicts, as 
well as factors related to opportunistic elite behavior in pursuit of power. The debate over 'greed and grievance' has been eclipsed by an appreciation that the two approaches are not unrelated. In situations of weak states, unequal distribution of resources, unstable social relations, a history of violence, and the existence of continually excluded subordinate groups, the emergence of mobilized resistance or 'political entrepreneurs' who organize for violent conflict is more likely to occur. The consequences may be political breakdown, civil war, inter-group riots, acts of violence, mass protests against the state, and in the worst instances crimes against humanity.

The search for 'root' or structural causes of conflict lies in efforts to find the underlying and sometimes elusive source of violence. While ethnic enmity, religious intolerance, or hate speech are often manifestations of conflicts, many analysts see the ultimate 'causes' of conflict in the deep-seated social structures that give rise to group grievances. Issues of natural resource management, especially of high-value commodities such as oil, access to employment, the absence of water and food security, lack of affordable, decent housing, or systematic economic discrimination-all have been seen as strong underlying drivers of conflict that have over time erupted into violent conflict. People are deprived of their basic human needs and will use all means available-including violence-to pursue and fulfill these needs.

Understanding economic structures and factors is critical to a full appreciation of the linkages between democracy and human security, for to have any impact on these causes of conflict, action at the national level and-in an era of global economic interdependence-changes in the international economic order are both required. In order to address the economic dimensions of conflict, democracy must be able to generate public goods-things that benefit everyone equally - and to manage the distribution of opportunity and wealth in society equitably. Economic duress is understandably a background 'cause' of conflict, and economic conditions have also prolonged violent confrontation once it has begun. The recent focus on economic conditions reflects the results of research that shows that common ingredients of violent conflict are often found in the economic structures and the factors that underlie social organization and affect political competition.

Modern internal conflicts are global problems that require a multilateral response. Internal conflicts have direct implications for neighboring states through spillovers, such as refugee flows or the spread of weapons, and indirect implications for the entire international community (such as the violation of international norms on crimes against humanity, or the creation of humanitarian emergencies). Indeed, most conflicts today are regionalized through the involvement of neighboring states and communities, for example, when there are ethnic groups involved in a struggle that transcends international borders. Ethnic groups may have ethnic kin in neighboring states and usually this provokes that king of fear, that restive minorities in one state may provoke grievances in nearby states as well. Such regionalized internal conflicts may be less amenable to peacemaking by the international community because trans-border linkages provide support and encouragement to the combatants.

Increasingly in today's wars, civilians are targeted directly; the historically sharp line between military combatants and civilians has become distinctly blurred. While reliable data on the total number of civilian deaths in today's armed conflicts do not exist, the toll on civilian lives is reflected in the exponential increase in the numbers of refugees today's wars generate. In early 2005, there were an estimated 17 million refugees, internally displaced and stateless persons around the world; the vast number of these refugees and displaced were homeless as a result of armed conflicts (Large \& Sisk 2006).

\section{Ethnic Heterogeneity and Conflict Disputes}

Several authors have stressed the importance of ethnic heterogeneity in the explanation of growth, investment, the efficiency of government, or civil wars. Their theoretical arguments, as they recognize explicitly, however, are based on "polarized societies," Theories of ethnic conflict often assume that the cause of political violence is the same across actors and constant over time. Causes differ, depending upon the identity, grievances, and strategy of the perpetrator as influenced by the cultural, economic, and political contexts in which they operate.

The effect of ethnic polarization on growth follows a more indirect channel: the choice of poor public policies, which in the end, negatively influences long-run growth. In particular, ethnic polarization transforms economic policy via a rentseeking mechanism. Additionally, ethnic polarization generates problems in the design of structural policies related to infrastructure and education. Several authors have interpreted the finding of a negative relationship between ethnic diversity and growth to be a consequence of the high probability of conflict associated with a highly fractionalized society.

Therefore ethnic dominance, or the existence of a large ethnic group, although close to being a necessary condition for a high probability of ethnic conflict, is not sufficient. You also need the minority to be large and not divided into many different groups. 
Since the end of the cold war in 1989, the world has seen an ongoing 'wave' of democratization. Some 100 countries have undergone transitions to democracy since the 1970s, with some 40 countries having done so in the 1990s and early 2000s. In 2005, a wide variety of countries experienced political change seen as having elements of democratization in very varying degrees-Egypt, Hong Kong, Georgia, Liberia, Ukraine, Togo and Lebanon, for example. There is no way of knowing whether such trends will continue, or whether non-democratic countries (such as China at the national level) will find a different pathway to political reform. The democratization trends of the 1990s and early 2000s raise a number of important retrospective questions about the underlying drivers of democratization, the various paths that countries go down on the road to democracy, whether such changes are sustainable over time, and why they are sustainable or not.

\section{Does Democracy Generate Conflict?}

Democracy like any other political system, is not without its flaws in this imperfect world. But in the absence of a better alternative, experience from around the world convinces us that democratic structures, in their myriad permutations, can offer an effective means for the peaceful handling of deep-rooted difference through inclusive, just and accountable social frameworks. Democratic systems of government have a degree of legitimacy, inclusiveness, flexibility and capacity of constant adaptation that enables deep-rooted conflicts to be managed peacefully. Moreover, by building norms of behavior of negotiation, compromise, and co-operation amongst political actors, democracy itself has a pacifying effect on the nature of political relations between people and between governments.

Despite the importance of democracy and democratic solutions, however, poorly designed democratic institutions can also inflame communal conflicts rather than ameliorate them. And the introduction of "democratic" politics can easily be used to mobilize ethnicity, turning elections into "us" versus "them" conflicts. In deeply divided societies, a combination of majoritarian political institutions and elections can often make things worse. Other democratic institutions that lend themselves towards divisive, yes or no political campaigns, such as referendums, can also have negative effects in divided societies. That is why basic democratic values such as pluralism, tolerance, inclusiveness, negotiation and compromise are keys to building lasting settlements to conflicts.

In virtually every major region of the world there are examples of ways in which democratic political competition has exacerbated underlying social tensions. Violence debilitates support for democracy by polarizing societies and undermining the social cohesion necessary for political compromise, while threatening the very security and human development imperatives that democracy must deliver if it is to remain legitimate In many societies today where ethnic, religious, racial or class divisions run deep, democratic competition does indeed inspire and inflame political violence. Violence is often a tool to wage political struggles-to exert power, rally supporters, destabilize opponents, or derail the prospect of elections altogether in an effort to gain total control of the machinery of government.

Some democratization processes have generated sufficient social tensions to contribute to their own demise. Political reform generates new tensions among winners and losers. After civil wars, some parties retain the ability to wage violence through their continued organization of militias, for example, and thus may be unwilling to accept loss of power at the ballot box, and retain the military power to challenge the elected regime. Edward Mansfield and Jack Snyder argue that young, immature democracies are more prone to interstate (international) war. They write that 'elites, including some who have parochial interests in empire and war, often attempt to maintain their position by using populist, nationalist themes to mobilize support.

Similarly, scholarly research has shown that democratization during times of economic stress is especially challenging and may lead to social conflict. Changes in the governing coalition may fundamentally rearrange economic relationships in society, for example along class lines, and this may unleash social unrest among those whose interests are threatened by such change.

Inequality is not a barrier to initial democratization, as situations such as those of India and South Africa show, but the transforming of social relations is exceptionally difficult to achieve over time. Democratization as a conflictexacerbating phenomenon is linked to the issues of certainty and uncertainty in the process of political change. Democratization as change can introduce uncertainty that is intolerable for some protagonists because they fear the consequences of the process; violence can occur to stop the process of democratization or to change its direction and outcome. On the other hand, democratization as a process can be too certain; protagonists know they may lose, and lose heavily, in elections or in negotiations and the certainty of such loss prompts violence to influence the process or the outcome. 
The debacle of the dissolution of the former Yugoslavia in 1989 underscores the concern with rapid democratization as potentially conflict-inducing. The onset of elections after socialism in a situation where political parties quickly crystallized around ethno-nationalist identities set the stage for the violent break-up of the former state. Democratization introduced divisive tendencies because of the complexity of multilayered identity. There was no experience of plural political party membership or of organizing for advocacy on an issue basis. When competitive electoral politics was introduced (after years of rule by a centralized party) amid financial crisis and uncertainty, the 'fallback' for mobilization was nationalism (Slovenian, Croatian, Serbian, Albanian etc.). Electoral competition combined with strong historical identities and sharp economic decline introduced insecurity and fear. The population responded, understandably, by closing ranks in nationalist identity. Electoral competition among political parties quickly became a struggle for group hegemony in the new and untested countries to emerge from the collapsing Yugoslav federation.

\section{Conclusions}

In this paper we saw that under a democracy, by contrast, disputes arise, are processed, debated and reacted to, rather than being resolved definitively and permanently. All outcomes are temporary, as the loser today may be the winner tomorrow. Unlike other systems, democratic government permits grievances to be expressed openly and responded to. In short, democracy operates as a conflict management system without recourse to violence. It is the ability to handle conflicts without having to suppress them or to be engulfed by them which distinguishes democratic government from its major alternatives. This does not mean that democracy is perfect, or that democratic governance will itself lead to peaceful outcomes.

In this paper we have provided a simple theory of social distributive conflict which emphasizes the importance of the porosity of social-group boundaries. Ethnicity provides a technology for group membership and exclusion which is used to avoid indiscriminate access to the spoils of conflict. It is natural to try to use the insights of the model to suggest policy recommendations to minimize the incidence of conflict along ethnic lines. The model suggests that economic development alone will remove the incentives for ethnic conflict, particularly if it is ac companied, as it often is, by a structural transformation where control over natural resources plays a smaller and smaller role; Secondly, ethnic conflict is sometimes preemptive, in that the stronger group preempts with conflict to protect itself from aggression by a smaller group

Perhaps most interestingly, the paper suggests that any policy that blurs sharp distinction between groups will reduce the incidence of ethnic conflict.

Although we presented several historical examples of ethnic conflict that are consistent with the premise of this paper, there is a clear sense in which the data required to fully test the implications of the model are not yet available.

Ethnic mobilization is a doubled-edged sword. In some way, conflict itself is not necessarily a negative process. Indeed, conflict is one of the most powerfully positive factors for change in a society. The nature of competitive representative democracy, for example, involves a certain degree of conflict between opposing forces, ideologies and parties.

\section{References}

Horowitz, Donald L. Ethnic groups in conflict. Berkeley: University of California Press, 1985.

Stewart, F. (2002) Horizontal inequalities: a neglected dimension of development, QEH Working Paper Series, No., pp. 81.

Large, J. \& Sisk, D.T Democracy, Conflict and Human Security, IDEA,Stockholm, Sweden, 2006

Hayson Nicholas, Conflict Resolution, Nation-Building \&Constitution Making, New England Journal of Public Policy 